\title{
MIR509-2 wt Allele
}

National Cancer Institute

\section{Source}

National Cancer Institute. MIR509-2 wt Allele. NCI Thesaurus. Code C142766.

Human MIR509-2 wild-type allele is located in the vicinity Xq27.3 and is approximately 91 bases in length. This allele, which encodes MIR509-2 pre-miRNA, plays a role in gene silencing. 